\title{
KEARIFAN LOKAL MINUMAN TRADISIONAL TUAK DALAM MERAJUT HARMONI SOSIAL DI TAPANULI BAHAGIAN UTARA
}

\author{
Harisan Boni Firmando \\ Program Studi Sosiologi Agama, Institut Agama Kristen Negeri Tarutung \\ Sumatera Utara-Indonesia
}

Korespondensi: boni.harisan@iakntarutung.ac.id

\begin{abstract}
Abstrak: Tulisan ini bertujuan untuk melihat sejauh mana minuman tradisional tuak sebagai bagian dari kearifan lokal bermanfaat bagi individu dan masyarakat. Penelitian ini menggunakan metode kualitatif dengan teknik pengumpulan data yaitu observasi, wawancara, dan studi dokumen. Hasil penelitian menunjukkan bahwa, bagi individu tuak merupakan minuman yang bermanfaat bagi kesehatan sedangkan bagi masyarakat tuak berfungsi sebagai alat untuk bersosialisasi. Seiring dengan produksi tuak yang berkualitas perlu dilakukan pengembangan kedai (lapo) tuak menjadi tempat yang bersih dan nyaman, sehingga pengunjung yang datang dapat menjadi pelanggan. Kepercayaan Batak tradisional menjadikan tuak sebagai sajian untuk roh-roh nenek moyang atau orang yang sudah meninggal, kini penyajian tuak menjadi berkembang pada berbagai acara dukacita dan sukacita. Dengan demikian minuman tradisional tuak memiliki fungsi kesehatan, fungsi ekonomi, fungsi sosial, fungsi keagamaan (religi), dan fungsi simbolik sehingga dapat merajut harmoni sosial.
\end{abstract}

Kata Kunci: Kearifan Lokal, Minuman Tradisional, Tuak 


\section{A. Pendahuluan}

Kearifan lokal adalah bagian dari budaya suatu masyarakat yang tidak dapat dipisahkan dari masyarakat. Kearifan lokal diwariskan secara turun-temurun melalui cerita atau sastra lisan dari generasi ke generasi. Kearifan lokal diartikan sebagai kearifan dalam kebudayaan tradisional suku-suku bangsa. Kearifan dalam arti luas tidak hanya berupa norma-norma dan nilai-nilai budaya, melainkan juga segala unsur gagasan, termasuk yang berimplikasi pada teknologi, penanganan kesehatan, dan estetika. Dengan pengertian tersebut maka yang termasuk sebagai penjabaran kearifan lokal adalah berbagai pola tindakan dan hasil budaya materialnya (Sedyawati, 2006: 382).

Minuman adalah segala sesuatu yang dapat di konsumsi dan dapat menghilangkan rasa haus, minuman merupakan kebutuhan pokok manusia. Sedangkan tradisional adalah suatu kebiasaan yang berasal dari leluhur yang diturunkan secara turun-temurun dan masih dijalankan hingga saat ini. Dengan demikian minuman tradisional adalah segala sesuatu yang diwarisi manusia dari leluhur secara turun temurun, yang biasa dikonsumsi oleh masyarakat dengan menggunakan bahan-bahan dari alam dan telah menjadi ciri khas dari suatu daerah serta memiliki cita rasa yang sesuai dengan selera masyarakat.

Tuak merupakan minuman tradisional yang terbuat dari sadapan, diambil dari mayang enau atau aren. Sadapan dari enau atau aren disebut nira, nira tersebut manis rasanya. Terdapat dua jenis tuak sesuai dengan resepnya, ada yang manis dan pahit, dimana yang pahit mengandung alkohol. Dalam bahasa Batak Toba pohon enau atau aren dinamai bagot. Di Tapanuli bahagian utara yang berketinggian sekitar 900 meter di atas permukaan laut, banyak bagot tumbuh sendiri. Bagot inilah yang digunakan untuk menyadap tuak. Pada daerah yang ketinggiannya hampir sama dengan permukaan laut, bagot tidak tumbuh, oleh karena itu penyadap mengambil sadapan dari pohon kelapa. Setelah sadapan tersebut diproses, minuman itu tetap dinamai tuak.

Pada awalnya tuak dijual dibawah pohonnya sendiri, kemudian tuak dijual di rumah paragat (penyadap tuak). Seiring berjalannya waktu muncul pakter tuak (kedai tuak). Di kedai tuak orang biasanya meminum tuak. Kehadiran kedai tuak 
memiliki berbagai fungsi dalam masyarakat Batak Toba. Fungsi tuak dan kedai tuak begitu luas, meskipun banyak persepsi negatif dari masyarakat mengenai tuak dan kedai tuak. Ada yang mengatakan banyak orang yang bermalas-malasan dan tidak mengingat waktu di kedai tuak. Ada juga yang mengatakan tuak membuat mabuk, bahkan mengatakan kedai tuak sebagai sumber keributan.

Tuak merupakan minuman tradisional berbagai suku di Indonesia termasuk bagi suku Batak Toba. Disamping berbagai penilaian negatif yang diberikan kepada tuak, tuak adalah produk multifungsi warisan nenek moyang yang merupakan kearifan lokal masyarakat Batak Toba. Tuak berfungsi bagi orang perorang maupun masyarakat umum. Bagi individu tuak merupakan minuman yang bermanfaat bagi kesehatan sedangkan bagi masyarakat umum tuak berfungsi sebagai alat untuk bersosialisasi.

Kearifan lokal minuman tradisional tuak merupakan warisan nenek moyang yang bernilai tinggi, yang dapat memperkuat identitas dan jati diri bangsa. Meskipun kini banyak variasi dan pola penyajian tuak, hal tersebut dianggap wajar dan merupakan inovasi yang perlu dikembangkan. Secara umum minuman tradisional tuak memiliki berbagai fungsi diantaranya untuk menjalin ikatan sosial, kerukunan sosial, mempererat persaudaraan, termasuk penanaman nilai-nilai budaya. Dengan demikian minuman tradisional tuak memiliki fungsi kesehatan, fungsi ekonomi, fungsi sosial, fungsi keagamaan (religi), dan fungsi simbolik. Prospek kearifan lokal minuman tradisional tuak sangat bergantung kepada bagaimana masyarakat melestarikan dan mengembangkan tuak agar dapat diterima oleh masyarakat dan berdaya saing di era modern.

Fokus utama dalam tulisan ini mendeskripsikan kearifan lokal minuman tradisional tuak. Adanya indikasi kuat bahwa saat ini semakin banyak kedai tuak yang berdiri, bahkan banyak kedai tuak yang telah tetata rapi. Berkembangnya kedai tuak memberi berbagai dampak negatif dan positif bagi masyarakat. Banyaknya persepsi masyarakat yang negatif terhadap tuak dan kedai tuak menutup berbagai dampak positif kehadiran tuak dan kedai tuak. Berdasarkan uraian di atas penelitian ini menggali kearifan lokal minuman tradisional tuak dalam merajut harmoni sosial. 
Menyikapi kearifan lokal ini perlu diketengahkan satu pertanyaan mayor: bagaimana kearifan lokal minuman tradisional tuak dapat menciptakan harmoni sosial? Adapun pertanyaan minornya: bagaimana proses produksi, distribusi dan konsumsi Tuak? Apa pengaruh tuak terhadap kehidupan sosial dan budaya masyarakat?

\section{B. Metode Penelitian}

Metode yang dipergunakan dalam studi ini adalah metode kualitatif, untuk memahami fenomena tentang apa yang dialami oleh subjek penelitian secara holistik, dengan cara mendeskripsikan dengan kata-kata dan bahasa, pada suatu konteks khusus yang alamiah dan dengan memanfaatkan berbagai metode alamiah. Kriteria individu yang menjadi informan kunci adalah tokoh adat dan tokoh agama yang merupakan pengurus dalam perkumpulan sosial seperti perkumpulan marga, serikat tolong menolong dan gereja. Sedangkan informan pelaku ditentukan bersamaan dengan perkembangan review dan analisis hasil penelitian saat penelitian berlangsung yaitu masyarakat, pengurus gereja dan generasi muda yang langsung merasakan hidup sebagai anggota masyarakat Batak Toba. Studi ini dilakukan di Empat Kecamatan, yaitu Kecamatan Parmaksian dan Kecamatan Porsea di Kabupaten Toba, serta Kecamatan Sipoholon dan Kecamatan Tarutung di Kabupaten Tapanuli Utara. Pemilihan Empat Kecamatan tersebut dikarenakan daerah tersebut merupakan kampung halaman masyarakat Batak Toba dan dalam kehidupan kesehariannya masyarakat yang bermukim di daerah tersebut merupakan anggota masyarakat Batak Toba, sehingga mengetahui bagaimana kehadiran tuak dapat menciptakan harmoni sosial.

\section{Pembahasan}

\section{Kegiatan Ekonomi; Produksi, Distribusi dan Konsumsi Tuak}

Tuak berasal dari pohon enau atau aren, yang merupakan pohon multifungsi bagi masyarakat Batak Toba. Semua bagian dari pohon enau dapat dijadikan bagianbagian dalam rumah adat tradisional Batak Toba, seperti batang pohon enau menjadi dinding rumah adat, ijuk pohon enau menjadi atap rumah adat. Helai daun pohon enau dijadikan sapu lidi dan buah pohon enau dibuat untuk makanan yang 
disebut dengan kolang kaling. Dengan demikian semua bagian dari pohon enau bermanfaat.

Tuak merupakan minuman yang terbuat dari sadapan, diambil dari mayang enau atau aren. Sadapan dari enau atau aren disebut nira. Nira kemudian difermentasi sehingga menjadi putih, menimbulkan bau yang khas serta memberi selera bagi peminumnya.

Penyadap tuak dalam bahasa Batak Toba disebut paragat, agat semacam pisau yang dipakai sewaktu menyadap tuak. Paragat terlebih dahulu menyeleksi buah enau yang diperkirakan bisa menghasilkan air nira. Apabila tandan buah yang cocok sudah ditemukan, paragat kemudian membersihkan pangkal batang buah enau itu dan memukulnya dengan balbal-balbal, alat yang terbuat dari kayu, yang dikhususkan untuk menyadap (maragat). Setelah tandan buah dipukul berulangulang selama beberapa minggu, baru dipotong mayangnya. Kemudian paragat membungkus ujung tandan tersebut dengan obat yang terbuat dari kapur sirih atau keladi yang ditumbuk selama dua-tiga hari. Dengan prosedur ini barulah mulai datang airnya dengan lancar. Seorang paragat menyadap tuak dua kali sehari, yakni pagi dan sore hari. Tuak yang ditampung pagi hari dikumpulkan di rumah paragat. Setelah rasanya diuji coba, paragat memasukkan ke dalam bak tuak sejenis kulit kayu yang disebut raru supaya cocok rasa dan alkoholnya, dimana kadar alkohol tuak berbeda-beda tergantung daerah pembuatannya. Raru inilah yang mengakibatkan peragian.

Resep membuat tuak berbeda-beda sedikit tergantung para paragat. Paragat harus belajar dahulu cara kerja membuat tuak, sehingga siapa saja dapat berhasil sebagai paragat. Biasanya anak seorang paragat mengikuti orang tuanya untuk belajar membuat tuak yang berkualitas. Mayoritas paragat tuak berjenis kelamin laki-laki, hampir tidak ada paragat yang berjenis kelamin perempuan, ini dikarenakan aktivitas paragat sehari-hari yang berat untuk perempuan. Paragat harus turun ke jurang, menaiki pohon bagot dan membawa tuak yang tertampung ke kampung.

Dari segi ekonomi tuak adalah sumber mata pencaharian masyarakat. Terdapat berbagai usaha berbasis ekonomi kerakyatan yang berasal dari tuak, diantaranya usaha lapo tuak dan usaha gula merah/aren. Sebagian paragat 
membuka kedai tuak sendiri, tetapi pada umumnya sebagian besar paragat menjual tuak kepada kedai atau agen tuak. Harga tuak berkisar Rp.2000,- (segelas), Rp. 5.000,- (setengah teko) dan Rp. 10.000,- (seteko). Dengan demikian paragat mendapat uang tunai setiap hari dari penjualan tuaknya. Gula merah bahan bakunya adalah nira. Proses pembuatannya serupa dengan pembuatan gula kelapa pada umumnya. Nira direbus dalam kuali semalaman sampai kental, kemudian dicetak mengunakan tabung-tabung bambu. Usaha gula merah merupakan usaha berskala mikro (rumahtangga) yang dapat meningkatkan pendapatan masyarakat.

Tuak dapat dikembangkan sebagai potensi ekonomi di Tapanuli Bahagian Utara yang merupakan kawasan Danau Toba. Kawasan Danau Toba saat ini merupakan destinasi wisata super prioritas yang ditetapkan Presiden Republik Indonesia. Usaha tuak yang masih tradisional dapat dikembangkan menjadi industri minuman dan makanan modern. Tuak dapat diproses dengan teknologi modern sehingga lebih awet, higienis, dan terukur kadar alkoholnya. Tuak dapat diproduksi dengan beragam variasi; tuak bebas-alkohol atau yang dikenal dengan tuak manis, tuak alkohol 2.5 persen, dan tuak beralkohol maksimal 5.0 persen. Tuak dapat dikemas dalam botol-botol cantik berbagai ukuran untuk dipasarkan kepada wisatawan. Tuak juga dapat diolah menjadi beragam makanan yang disebut kuliner bagot, seperti aneka kue. Salah satu kue olahan yang dikembangkan adalah kue tungkup/panukkup yang disebut pancake batak.

Seiring dengan produksi minuman dan makanan yang berkualitas perlu pula dilakukan pengembangan lapo tuak. Lapo-lapo tuak dapat dikembangkan menjadi tempat yang bersih dan nyaman, serta menyajikan minuman dan makanan yang bermutu. Dengan demikian pengunjung yang datang dapat menjadi pelanggan. Adapun cara untuk mempertahankan pelanggan adalah memberikan kepuasan pelanggan yang tinggi. Sehingga akan lebih sulit bagi saingan untuk menerobos halangan dengan menawarkan harga lebih murah atau rangsangan lain (Sunyoto, 2014: 233-234). Pelanggan adalah sumber pendapatan dan keuntungan, pelanggan yang puas bukan saja akan kembali lagi melainkan akan membawa teman-teman atau sanak famili yang diharapkan akan menjadi pelanggan-pelanggan baru. Usahawan tidak cukup hanya dengan mengejar kepuasan pelanggan melainkan bagaimana bisa menjaga, peduli terhadap komplain pelanggan sekecil apapun dan 
dijaga agar tetap menjadi pelanggan yang setia selama bisnis beroperasi (Basrowi, 2011: 100). Pelayanan pelaku usaha lapo yang ramah perlu ditingkatkan serta harga yang minuman dan makanan yang wajar dan terjangkau sangat perlu diterapkan untuk peningkatan sektor perdagangan di Tapanuli Bahagian Utara. Suasana ini memberikan kesan yang baik bagi pengunjung lapo sehingga dapat menjadi strategi promosi yang efektif dalam menjaring wisatawan dari dalam dan manca negara.

\section{Tuak Dalam Keseharian Masyarakat}

Perilaku merupakan suatu tindakan sosial manusia yang sangat mendasar. Perilaku merupakan tindakan atau kegiatan yang dilakukan seseorang atau sekelompok orang untuk kepentingan atau pemenuhan kebutuhan tertentu berdasarkan pengetahuan, kepercayaaan, nilai dan norma kelompok yang bersangkutan (Kalangie, 1996: 87). Perilaku masyarakat meminum tuak menambah beragam istilah yang diberikan untuk tuak yang disebut susu Batak. Tuak disebut bir panjat karena penyadap tuak memanjat pohon enau. Tuak yang diminum pagi hari disebut tupa, tuak yang diminum siang hari disebut tusi, tuak yang diminum sore hari disebut tusor.

Masyarakat Batak Toba memiliki pengetahuan dalam memproduksi tuak dan percaya terhadap berbagai manfaat meminum tuak. Masyarakat percaya tuak berkhasiat untuk kesehatan karena mengandung antioksidan. Letak geografis wilayah Tapanuli Bahagian Utara yang berhawa dingin menyebabkan masyarakat mengkonsumsi tuak, karena bagi masyarakat tuak berkhasiat untuk menghangatkan tubuh.

Sebagian besar wanita Batak Toba tidak meminum tuak, walau tidak dapat dipungkuri ada wanita yang meminum tuak. Kearifan lokal masyarakat Batak Toba menyarankan agar wanita yang baru melahirkan anak meminum tuak. Tuak bermanfaat bagi ibu yang menyusui karena tuak mengandung nutrisi dan memberi perlindungan kondisi Air Susu Ibu (ASI), sehingga menghasilkan ASI yang berkualitas. Tuak dapat meningkatkan kemampuan visual dan laktasi atau produksi serta memperlancar pengeluaran ASI dari payudara. Tuak membuat Ibu yang baru melahirkan berkeringat banyak guna mengeluarkan kotoran-kotoran dari badannya. Wanita yang baru melahirkan dianjurkan meminum tuak setiap kali merasa haus, sebagai ganti air minum, paling sedikit selama satu minggu setelah 
melahirkan anak. Sebagian masyarakat juga menganjurkan wanita yang menyusui meminum tuak tidak lebih dari satu gelas agar manfaat tuak tidak hilang. Tidak semua wanita Batak Toba yang baru melahirkan meminum tuak, saat ini telah jarang ditemukan kebiasaan meminum tuak bagi wanita yang baru melahirkan dan menyusui anak, kini muncul kebiasaan meminum bir hitam, susu atau obat sesuai dengan selera dan kemampuan untuk memperlancar air susunya. Hal ini disebabkan timbulnya rasa pening dan mabok apabila meminum tuak.

Masyarakat percaya tuak dapat mengurangi bahkan menjadi obat dari berbagai penyakit. Masyarakat Batak Toba percaya tuak dapat mengatasi sembelit dan penyakit ginjal. Sembelit yang tidak segera diatasi dapat beresiko mengalami gangguan kerja ginjal. Pemicu utama yang menyebabkan terjadinya sembelit ialah kurangnya serat di dalam makanan yang di konsumsi sehari-hari. Serat sangat di butuhkan oleh tubuh, tuak memiliki manfaat untuk mengatasi sembelit. Sembelit dapat teratasi dengan cepat serta lancar apabila kita rutin mengonsumsi tuak.

Tuak mampu menjadi obat untuk penyakit diabetes. Penyakit diabetes merupakan salah satu jenis penyakit yang sangat berbahaya dan juga ditakuti karena penyakit ini dapat menyebabkan kematian. Dengan meminum tuak secara teratur dengan dosis yang rendah akan dapat mengurangi kadar gula darah.

Dengan meminum tuak yang tidak berlebihan dapat menurunkan demam. Tuak bermanfaat menurunkan demam pada anak dan orang dewasa. Demam terjadi karena berkurangnya sistem kekebalan dalam tubuh. Kandungan dalam tuak dapat membantu meningkatkan sistem kekebalan serta memperlancar metabolisme tubuh sehingga membantu menurunkan demam.

Tuak dapat merubah suasana menjadi lebih baik dan tenang. Khasiat minuman tuak ini dapat dimanfaatkan sebagai obat tidur penenang. Apabila seseorang mengalami masalah sulit untuk tidur mereka dapat mengonsumsi tuak agar tidur nyenyak dan menyegarkan tubuh setelah bagun dari tidur.

Tuak bermanfaat untuk menenangkan hati hingga pereda dan menghilangkan stress. Tuak dapat memberikan efek relaksasi, dimana tuak membuat hati serta pikiran menjadi lebih tenang. Orang Batak Toba kerap datang ke kedai tuak apabila sedang stres. Di kedai tuak orang Batak Toba bisa menikmati tuak sambil bercerita dengan teman, sambil bernyanyi dan bermain musik. 


\section{Tuak Dalam Pergaulan Dengan Sahabat Karib}

Gaya hidup merupakan cara-cara terpola dalam menginvestasikan aspekaspek tertentu kehidupan sehari-hari dengan nilai sosial atau simbolik; tetapi ini juga berarti bahwa gaya hidup adalah cara bermain identitas (Chaney, 1996: 92). Gaya hidup ini dapat dilihat pada berbagai daerah di Tapanuli Bahagian Utara, dimana biasanya pada sore hari laki-laki yang telah selesai bekerja berkumpul di lapo. Mereka berbincang-bincang, bermain kartu, bercatur, mendengar radio, menonton televisi, bernyanyi dan bermain musik, sambil meminum tuak. Untuk menambah kenikmatan, meminum tuak di iringi dengan memakanan ikan dan daging yang disebut dengan tambul, sehinggga suasana menjadi semarak bercampur canda dan tawa. Seseorang dapat meminum tuak beberapa gelas dalam sehari. Kaum laki-laki, baik muda maupun tua meminum tuak di lapo, namun jarang terdapat perempuan yang meminum tuak di lapo bersama laki-laki, kecuali pemilik lapo atau isterinya. Ada juga laki-laki yang membeli tuak di lapo dan membawa tuak yang dibeli ke rumahnya atau ke rumah temannya untuk diminum bersama.

Masyarakat hanya mengonsumsi citra yang melekat pada barang tersebut (bukan lagi pada kegunaannya) sehingga masyarakat sebagai konsumen tidak pernah merasa puas dan akan memicu terjadinya konsumsi secara terus menerus, karena kehidupan sehari-hari setiap individu dapat terlihat dari kegiatan konsumsinya, barang dan jasa yang dibeli dan dipakai oleh setiap individu, yang juga didasarkan pada citraan-citraan yang diberikan dari produk tersebut (Murti, 2005: 38). Tuak menjadi barang yang dikonsumsi oleh masyarakat. Kebiasaan meminum tuak tidak berhubungan dengan status sosial-ekonomi seseorang, melainkan berkaitan dengan usia dewasa seseorang. Lelaki yang sudah dewasa akan cenderung meminum tuak. Peminum tuak bukan masyarakat yang berada pada tingkat ekonomi menengah ke bawah seperti petani, supir, pekerja bangunan, namun juga masyarakat yang berada pada tingkat ekonomi menengah ke atas seperti pegawai swasta, pegawai negeri ataupun pejabat di pemerintahan.

Bagi masyarakat Batak Toba pergaulan dengan sahabat karib dilaksanakan di lapo (kedai tuak atau kedai kopi) sambil markombur dan marnonang. Markombur dan marnonang telah menjadi kebiasaan bahkan membudaya pada masyarakat Batak Toba. Markombur merujuk kepada kegiatan diskusi dalam rangka 
menghabiskan waktu luang tanpa mempertimbangkan esensi ataupun manfaat dari topik yang dibahas. Sedangkan marnonang bukan bertujuan untuk menghabiskan waktu luang melainkan untuk mengisi waktu luang dengan hal-hal yang memberi pencerahan. Umumnya pelaksanaan makombur dan marnonang pada sore hingga malam hari setelah orang pulang dari tempat bekerja seperti dari sawah atau kantor. Markombur dan marnonang dilaksanakan dalam suasana informal yang rileks dan santai, menimbulkan canda tawa sehingga orang yang terlibat merasa tidak bosan. Topik yang didiskusikan bermacam-macam, seperti hal-hal yang berkaitan dengan kehidupan sehari-hari hingga kehidupan mendatang.

Pemilik lapo (Parlapo) telah memiliki pelanggan tetap yang selalu bahkan setiap hari datang ke laponya untuk meminum tuak. Seseorang dapat dikatakan sebagai pelanggan apabila orang tersebut mulai membiasakan diri untuk membeli produk atau jasa yang ditawarkan oleh suatu perusahaan. Kebiasaan tersebut dapat dibangun melalui pembelian berulang-ulang dalam jangka waktu tertentu, apabila jangka waktu tertentu tidak melakukan pembelian ulang maka orang tersebut tidak dapat dikatakan sebagai pelanggan tetapi sebagai seorang pembeli atau konsumen (Musanto, 2004: 128).

Menurut Baudrillard, ciri dari masyarakat konsumen adalah masyarakat yang didalamnya terjadi pergeseran logika konsumsi yaitu dari logika kebutuhan menjadi logika hasrat, masyarakat tidak mengonsumsi nilai guna produk melainkan nilai tanda (Suyatno 2013 : 107-110). Meminum tuak di lapo mempunyai alasan tersendiri bagi masyarakat batak, dimana lapo menjadi tempat masyarakat untuk bersosialisasi. Sebagaimana Douglas dan Isherwood dalam Featherstone berpendapat, bahwa dalam masyarakat saat ini barang-barang digunakan untuk membangun hubungan-hubungan sosial (Featherstone, 1992: 14). Markombur dan marnonang merupakan salah satu bentuk kegiatan bersama dengan modal sosial yang tinggi. Kebiasaan markombur dan marnonang memberikan inspirasi dan transfer ilmu pengetahuan dari satu individu ke individu yang lain. Ilmu pengetahuan yang ditransfer mulai dari bidang budaya seperti adat istiadat, pemerintahan, politik hingga sektor usaha. Dalam sektor usaha, apabila ada pengusaha yang kekurangan tenaga, dapat dibantu oleh orang yang lain, yang merupakan ale-ale (sahabat karib) di lapo. 
Sebagai tempat bersosialisasi lapo menjadi sumber informasi bagi masyarakat. Di lapo masyarakat mendapatkan berbagai informasi, mulai dari informasi lokal, nasional hingga mancanegara melalui interaksi yang terjadi diantara pengunjung lapo. Pengunjung lapo akan mengetahui kapan diadakan acara suka dan duka di daerahnya melalui perbincangan dengan pengunjung yang lain, sering kali pihak keluarga yang akan melaksanakan pesta menjalankan undangan di lapo. Berbagai pengumuman, acara dan program yang dilaksanakan pemerintah juga disosialisasikan di lapo oleh perangkat desa atau dinas terkait. Pengumuman, acara dan berbagai program pemerintah seringkali ditemui di lapo dengan menggunakan alat sosialisasi seperti undangan, poster, hingga spanduk. Lapo juga menjadi tempat berkumpulnya beragam komunitas formal dan informal, seperti kelompok tani dan kelompok memancing.

Pada berbagai daerah di Tapanuli Bahagian Utara banyak ditemui lapo yang buka hanya mengambil waktu dua sampai tiga jam saja, sekitar pukul 16.00 WIB19.00 WIB. Waktu ini merupakan waktu pulang kantor dari Pegawai Swasta maupun Pegawai Negeri Sipil, dimana pengunjung lapo umumnya para pegawai kantor. Lapo menjadi tempat dari pemerintah menyerap aspirasi dan usulan program pembangunan dari masyarakat secara informal. Seringkali melalui perbicangan di lapo para pejabat atau pengambil keputusan di pemerintahan daerah mendapatkan pencerahan ataupun ide-ide kreatif untuk pengembangan daerah dari masyarakat pengunjung lapo. Perbincangan informal dengan samasama meminum tuak membuat tidak ada rasa canggung dan jarak antara masyarakat umum dengan pejabat. Tidak adanya rasa canggung dan jarak ini berasal dari kepercayaan masyarakat bahwa dengan meminum tuak seseorang akan percaya diri, semakin berani berbicara dengan orang lain atau di depan umum, dengan demikian kehadiran tuak mempermudah komunikasi antar individu.

Lapo adalah ruang publik tempat sosialisasi yang tepat dalam menyambut pesta demokrasi seperti pemilihan kepala daerah dan pemilihan umum. Hal ini dikarenakan beragamnya masyarakat yang datang ke lapo dari segi usia dan mata pencaharian. Para calon kepala daerah, calon legislatif atau tim sukses adalah aktoraktor yang seringkali datang ke lapo untuk mensosialisasikan visi, misi dan berbagai program mereka kepada masyarakat. Aktor dipandang sebagai manusia yang 
mempunyai tujuan atau mempunyai maksud. Artinya aktor mempunyai tujuan dan tindakan yang tertuju pada upaya untuk mencapai tujuan itu. Aktor pun dipandang mempunyai pilihan atau nilai, keperluan yang penting adalah kenyataan bahwa tindakan dilakukan untuk mencapai tujuan yang sesuai dengan tingkatan pilihannya (Ritzer, 2014: 365). Di lapo para calon-calon tersebut berbincang santai dengan masyarakat dan akan semakin akrab apabila memiliki hubungan kekerabatan atau marga sehingga memunculkan rasa kekeluargaan. Di lapo para calon-calon tersebut mendapat dukungan dari masyarakat pemilih bahkan anggota tim sukses yang baru sehingga tujuan mereka untuk menang pada pesta demokrasi dapat tercapai.

\section{Tuak Dalam Upacara Adat Batak Toba}

Marx mengatakan bahwa ada dua aspek dalam komoditas, yaitu: use value dan exchange value. Nilai guna merupakan kegunaan suatu objek dalam pemenuhan kebutuhan tertentu, sedangkan exchange value menekankan pada nilai tukar yang terkait dengan nilai produk itu di pasar, atau objek yang bersangkutan (Lechte, 2001: 352). Tetapi, apa yang dinyatakan oleh Marx berbeda dengan Baudrillard. Sebuah objek tidak hanya memiliki use value dan exchange value, tetapi juga memiliki symbolic value dan sign value (Pawanti, 2013: 2). Maksud dari pernyataan tersebut bahwa orang tidak lagi mengonsumsi sebuah objek berdasarkan kegunaan dan nilai tukarnya, tetapi juga adanya nilai simbolik dan nilai tanda yang bersifat abstrak

Tuak pada awalnya manis, tuak yang manis dalam Bahasa Batak Toba disebut tuak na tonggi. Tuak berasal dari mayang bagot, awal mula keberadaan batang bagot ini dipercaya masyarakat Batak Toba dari cerita rakyat yang sudah turun temurun diceritakan. Dahulu ada seorang putri yang bernama si boru Sorbajati, dia dipaksa orang tuanya kawin dengan seorang laki-laki yang tidak disukainya. Orang tua si boru Sorbajati sudah menerima uang dan berhutang dengan laki-laki yang tidak disukainya itu. Untuk menunjukkan baktinya kepada orang tua akhirnya dia menyetujui desakan orangtuanya dengan meminta dibunyikan gondang (alat musik tradisional Batak Toba) untuk perkawinannya. Gondang kemudian dibunyikan dan si boru Sorbajati menari, sewaktu menari, tibatiba dia melompat kehalaman sehingga terbenam ke dalam tanah. Si boru Sorbajati kemudian menjelma menjadi pohon bagot, sehingga tuak disebut aek (air) Sorbajati. 
Karena perbuatan itu dianggap sebagai perbuatan terlarang, maka tuak tidak dimasukkan pada sajian untuk Debata (Tuhan).

Kepercayaan Batak tradisional menjadikan tuak sebagai sajian untuk rohroh nenek moyang atau orang yang sudah meninggal. Kini penyajian tuak berkembang pada berbagai acara dukacita dan sukacita. Pada awalnya tuak dijadikan sebagai minuman adat pada upacara adat resmi, seperti manuan ompuompu dan upacara manulangi hingga pada acara adat mangokkal holi (penggalian tulang belulang), kematian, perkawinan dan kelahiran.

Setelah diadakan acara penguburan terhadap orang yang sudah bercucu. Keesokan harinya dilaksanakan acara adat manuan ompu-ompu/raja ni duhutduhut. Acara ini merupakan penanaman beberapa jenis tumbuh-tumbuhan di atas tambak (kuburan). Tambak tradisional Batak merupakan kuburan dari tanah yang berlapis, dimana jumlah lapisannya menunjukkan tingkatan orang yang meninggal, apakah sudah berketurunan, bercucu atau bercicit, namun kini kuburan modern yang terbuat dari semen disebut juga tambak. Penanaman tumbuh-tumbuhan ini melambangkan banyaknya keturunan dari orang yang meninggal serta merupakan doa dan harapan agar seperti banyaknya tumbuh-tumbuhan yang ditanam, banyak pula keturunan almarhum yang tumbuh berkembang. Pada acara ini air dan tuak harus dituangkan pada tanaman di atas tambak, namun sekarang ini yang biasa dituangkan hanya air saja.

Dalam masyarakat Batak Toba terdapat upacara adat manulangi, yaitu acara memberikan makanan secara resmi kepada orang tua. Keturunan dari orang tua, anak-anak dan cucu memberikan makanan khas tradisional kepada orang tua tersebut. Keturunan orang tua yang memberi makan meminta restu dan nasehat dari orang tuanya dan pada kesempatan ini orang tua yang diberikan makanan membagikan harta kepada keturunannya, rangkaian acara manulangi disaksikan oleh keluarga besar dan pengetua-pengetua adat. Pada waktu memberikan makanan kepada orang tua, keturunannya harus menyajikan air minum serta tuak. Dalam kepercayaan masyarakat Batak Toba air dan tuak mengandung makna. Air disebut tio (jernih/jelas) yang dimaknai agar keturunan orang tua yang diberi makanan tio panggabean, tio parhorasan, diberi kesehatan dan keturunan yang baik. 
Sedangkan tuak disebut tonggi (manis) yang dimaknai agar keturunan orang tua yang diberi makanan diberi Tuhan pencaharian yang baik (tio paccarian).

Tuak berperan penting dalam kehidupan masyarakat Batak Toba. Peranan ini didapati pada upacara adat baik suka maupun duka, dimana pihak boru (pihak penerima isteri) memberikan tuak na tonggi (tuak yang manis) kepada pihak hulahula (pihak pemberi isteri). Pemberian tuak kepada unsur kerabat ini merupakan tindakan sosial. Tindakan sosial menurut Max Weber adalah suatu tindakan individu sepanjang tindakan itu mempunyai makna atau arti subjektif bagi dirinya dan diarahkan kepada tindakan orang lain. Suatu tindakan individu yang diarahkan kepada benda mati tidak masuk dalam kategori tindakan sosial, suatu tindakan akan dikatakan sebagai tindakan sosial ketika tindakan tersebut benar-benar diarahkan kepada orang lain (individu lainnya) (Ritzer, 2001: 126). Pemberian tuak na tonggi dilakukan pada saat acara manortor (menari) di tempat diadakannya upacara adat seperti di rumah, halaman rumah atau di gedung serbaguna. Dalam prosesi upacara adat Batak Toba juga ada pemberian pasi tuak na tonggi (untuk membeli tuak yang manis) berupa sejumlah uang dari pihak boru kepada hula-hula.

Littlejohn dalam bukunya yang berjudul Theories of Human Communication mengemukakan bahwa sosial budaya tempat kita tinggal akan menentukan apa yang kita kehendaki dan apa yang kita butuhkan yang kemudian akan merembet pada masalah cita rasa, pilihan, dan keinginan (Arsita, 2017: 90-91). Tuak yang berhubungan dengan upacara adat disebut tuak tangkasan. Tuak tangkasan merupakan tuak pilihan yang terbaik, dikatakan tuak terbaik karena akan diberikan boru kepada hula-hulanya. Masyarakat Batak Toba sangat menghormati hula-hula sebagai pihak pemberi isteri, sehingga apapun yang diberikan pihak boru kepada hula-hulanya harus yang terbaik, karena hula-hula telah memberikan borunya (anak perempuannya) dan anak perempuannya itu telah memberikan keturunan kepada pihak penerima isteri (boru). Tuak tangkasan yang diberikan boru kepada hula-hula pada awalnya tidak dicampur dengan dengan raru, namun kini sudah kerap tuak tangkasan yang diberikan dicampur dengan raru karena selera peninum tuak pada umumnya tuak dicampur dengan raru. Kini tuak disajikan disetiap acara bagi masyarakat Batak Toba untuk menjamu tamu. 


\section{Kesimpulan}

Masyarakat Batak Toba memiliki pengetahuan dalam memproduksi tuak dan percaya terhadap berbagai manfaat meminum tuak. Tuak berkhasiat untuk kesehatan karena mengandung antioksidan sehingga dapat mengurangi bahkan menjadi obat dari berbagai penyakit. Bagi individu tuak merupakan minuman yang bermanfaat bagi kesehatan sedangkan bagi masyarakat tuak berfungsi sebagai alat untuk bersosialisasi. Kebiasaan meminum tuak tidak berhubungan dengan status sosial-ekonomi seseorang, melainkan berkaitan dengan kedewasaan seseorang. Seseorang yang telah dewasa akan meminum tuak di lapo. Lapo menjadi ruang publik bagi individu untuk berinteraksi dan sosialisasi dengan individu lain.

Kepercayaan Batak tradisional menjadikan tuak sebagai sajian untuk rohroh nenek moyang atau orang yang sudah meninggal. Kini penyajian tuak berkembang pada berbagai acara dukacita dan sukacita. Pada awalnya tuak dijadikan sebagai minuman adat pada upacara adat resmi, seperti manuan oтриompu dan upacara manulangi hingga pada acara adat mangokkal holi (penggalian tulang belulang), kematian, perkawinan dan kelahiran.

Tuak dapat dikembangkan sebagai potensi ekonomi di Tapanuli Bahagian Utara yang merupakan kawasan Danau Toba. Kawasan Danau Toba saat ini merupakan destinasi wisata super prioritas yang ditetapkan Presiden Republik Indonesia. Usaha tuak yang masih tradisional dapat dikembangkan menjadi industri minuman dan makanan modern. Seiring dengan produksi tuak yang berkualitas perlu dilakukan pengembangan lapo tuak. Lapo-lapo tuak dapat dikembangkan menjadi tempat yang bersih dan nyaman, serta menyajikan minuman dan makanan yang bermutu. Dengan demikian pengunjung yang datang dapat menjadi pelanggan.

Kearifan lokal minuman tradisional tuak merupakan warisan nenek moyang yang bernilai tinggi, yang dapat memperkuat identitas dan jati diri bangsa. Minuman tradisional tuak memiliki berbagai fungsi diantaranya untuk menjalin ikatan sosial, kerukunan sosial, mempererat persaudaraan, termasuk penanaman nilai-nilai budaya. Dengan demikian minuman tradisional tuak memiliki fungsi kesehatan, fungsi ekonomi, fungsi sosial, fungsi keagamaan (religi), dan fungsi simbolik sehingga dapat merajut harmoni sosial. 


\section{Daftar Pustaka}

Basrowi, 2011. Kewirausahaan untuk Perguruan Tinggi. Bogor: Ghalia Indonesia.

Chaney, D. 1996. Lifestyle : Sebuah Pengantar Komprehensif. Yogyakarta: Jalasutra.

Featherstone, M. 1992. Consumer Culture and Postmodernism. London: Sage Publication

Kalangie, Nico, SS. 1996. Kebudayaan. Jakarta: Devisi dari Kesain Blang.

Lechte, J. 2001. 50 Filsuf Kontemporer. Yogyakarta: Kanisius.

Murti, A. 2005. Perbandingan Konsep Consumer Society dalam Pemikiran Jean Baudrillard dan Herbert Marcuse. Depok: Universitas Indonesia.

Ritzer, George. 2001. Sosiologi Ilmu Berparadigma Ganda. Jakarta: PT Rajawali Press.2001),126.

Ritzer, George, 2014. Teori Sosiologi Modern. Jakarta : kencana edisi ke 7.

Pawanti, M. H. 2013. Masyarakat Konsumeris Menurut Konsep Pemikiran Jean Baudrillard. Depok: Universitas Indonesia.

Sedyawati, Edy. 2006. Budaya Indonesia (Kajian Arkeologi, Seni, dan Sejarah). Jakarta: PT. Raja Grafindo Persada.

Sunanto, H. 1993. Aren: Budidaya dan Multigunanya. Yogyakarta: Penerbit Kanisius.

Sunyoto, Danang. 2014. Dasar-Dasar Manajemen Pemasaran (Konsep, Strategi, dan Kasus). Cetakan ke-1. Yogyakarta: CAPS (Center for Academic Publishing Service).

Suyatno, Bagong. 2013. Sosiologi Ekonomi : Kapitalisme dan Konsumsi di Era Masyarakat Post-Modernisme. Jakarta : Kencana.

Arsita, A. 2017. "Simulakra Baudrillard dalam Multidimensi Posmodernisme: Kajian Fotografi Makanan dalam Media Sosial Instagram". Jurnal Rekam, Vol.13 No.2.

Musanto, Trisno. 2004. "Faktor-Faktor Kepuasan Pelanggan dan Loyalitas Pelanggan: Studi Kasus pada CV. Sarana Media Advertising Surabaya". Jurnal Manajemen \& Kewirausahaan, Vol.6, No.2. 